\title{
Type 2 diabetes in Belgians of Turkish and Moroccan origin
}

\author{
by \\ Vandenheede $\mathrm{H}^{1,2}$, Deboosere $\mathrm{P}^{2}$
}

\begin{abstract}
Objectives

To compare the prevalence of type 2 diabetes in adults aged 35 to 74 years of the Turkish and Moroccan communities in Belgium with the prevalence in native Belgians. To examine the determinants and specific mechanisms responsible for differences in diabetes between these communities.

Method

Both objectives were examined using the Health Interview Surveys of 1997, 2001 and 2004. Stepwise logistic regression analyses were performed with diabetes as the outcome variable. The variables 'age', 'sex', 'ethnic origin', 'body mass index', 'lack of physical activity', 'educational attainment' and 'income' were introduced in the model in consecutive steps.

Results

In 35- to 74-year-olds, the prevalence of type 2 diabetes is higher in Belgians of Turkish and Moroccan origin than in native Belgians. In native Belgian men, the prevalence amounts to $5.0 \%$. In 35- to 74-year-old men of Turkish and Moroccan origin, the diabetes prevalence is $5.8 \%$ and $6.5 \%$ respectively. $4.3 \%, 18.7 \%$ and $11.9 \%$ of the women of Belgian, Turkish and Moroccan origin respectively suffer from diabetes. In men, differences in the prevalence of diabetes are strongly reduced after controlling for lack of physical activity and educational attainment. In women, differences remain high, although they become smaller after accounting for BMI and educational attainment.

Conclusions

In men, the differences in diabetes prevalence are explained by lifestyle factors and educational attainment. In women, the community differences in diabetes prevalence persist, although lifestyle factors and educational attainment play an important part in understanding these differences.
\end{abstract}

\section{Keywords}

Belgium, body mass index, diabetes mellitus, immigrants, Morocco, physical exercise, socioeconomic factors, Turkey

\footnotetext{
1 Research Foundation Flanders, Brussels, Belgium

2 Vrije Universiteit Brussel, Research Unit Interface Demography, Brussels Belgium

Correspondence: hadewijch.vandenheede@vub.ac.be
} 


\section{Introduction}

Type 2 diabetes mellitus is a severe metabolic disorder, of which the main characteristics are: a decreased glucose tolerance, glucose in the urine (glucosuria) and an increased blood sugar level (hyperglycaemia). This insulin resistant form of diabetes occurs predominantly at an advanced age (over 40 years old). Type 2 diabetes is linked to an increased death probability. It can however be curable, when patients lose a large amount of weight, as has been shown in studies of obesity surgery (1-3).

There is strong evidence that genetics play an important part in interaction with environmental factors. A hereditary susceptibility can develop into diabetes, if there are also environmental and/or lifestyle factors present, such as excess weight/obesity, abdominal obesity, a lack of physical activity, diet, stress and smoking $(1,4-8)$. Some authors also emphasise the link with the metabolic syndrome (9-11).

Prevalence estimates of diabetes - type 1 and 2 together - in Belgium vary between 2 and $5 \%$. This figure presents an underestimation of the actual prevalence of diabetes. It is estimated that one third to half of all diabetics are unaware of their situation $(1,4)$. Based on the Belgian Health Interview Surveys of 1997, 2001 and 2004 (HIS 97-01-04), we found a selfreported diabetes prevalence of $3.7 \%$. In the near future, the prevalence of diabetes is expected to rise. Worldwide ageing - amongst migrant populations as well - and increased corpulence are held responsible for this increase (1).

Ethnic differences in prevalence of type 2 diabetes are found in many countries (12-19). Clinical practice and research both strongly indicate a higher prevalence of diabetes ${ }^{1}$ in Belgians of Turkish and Moroccan origin (20-22). However, in general, the mortality of adult migrants from Turkey and Morocco is lower than that of native Belgians with a comparable socio-economic status (23). On the other hand, there is ample evidence that adult migrants have a health disadvantage compared to the host population (23-24). One of the explanations of this difference in health may be type 2 diabetes. Deboosere and Gadeyne (23) found an excess mortality rate from diabetes mellitus amongst Moroccan women living in Belgium (25 to 54 years old). Dutch research (14-17) also shows a higher prevalence of type 2 diabetes mellitus in persons of Turkish, Moroccan and Surinamese origin than in native Dutchmen.

Only a few Belgian studies have been published on the determinants and specific mechanisms responsible for the higher diabetes prevalence amongst Belgians of Turkish and Moroccan origin (21-22). To our knowledge, these studies are based on clinical data. The results have not yet been quantified in a sample, representative for the population of Turkish and Moroccan origin in Belgium. In the Netherlands, some authors (14-17) did examine risk factors responsible for the higher diabetes prevalence amongst persons of Turkish, Moroccan and Surinamese origin. They give diverging explanations: biological, cultural as well as socio-economic differences are hypothesised to account for the higher diabetes prevalence

\footnotetext{
${ }^{1}$ In this article, diabetes generally refers to type 2 diabetes unless mentioned otherwise.
} 
in these communities. With regard to the biological factors, three hypotheses are distinguished: the 'thrifty genotype', the 'genetically unknown food' and the 'thrifty phenotype' hypotheses $(13,17,25)$. Next to the biological explanations put forward by some authors, others mainly attribute the higher diabetes prevalence amongst migrant communities to lifestyle patterns and socio-economic factors $(12,15-17,22,26)$. The most commonly cited associated lifestyle patterns are diet - the composition of the diet as well as an excessively high total caloric intake -, excess weight/obesity and physical activity. All of these lifestyle patterns are not only strongly culturally related; they also have a strong socio-economic component (27). Thus, next to the biological and lifestyle factors, socio-economic determinants also play an important part in differences in diabetes prevalence $(4,22,26)$. Diabetes mellitus - and health and illness in a broader sense - is a social phenomenon. Diabetes contributes to the process of surviving and dying and is an outcome of a large and diverse set of risk factors during lifetime. Research by Kriegsman et al. (14) shows that a higher socioeconomic status is associated with a lower risk of type 2 diabetes mellitus, regardless of ethnic origin. Moreover, Dijkshoorn, Uitenbroek and Middelkoop (15) report a lower educational level as an important risk factor in the higher diabetes prevalence amongst the Turkish and Moroccan communities in the Netherlands.

To assess the relative value of these explanations, it is important to compare the diabetes prevalence in the immigrant-receiving countries, such as the Netherlands or Belgium, to the prevalence in the countries of origin. However, the comparability is generally poor, as reliable epidemiological data on the prevalence of type 2 diabetes in Turkey and Morocco are sparse. Moreover, in countries experiencing economic transition (like Turkey and Morocco), there are usually huge regional differences in diabetes prevalence rates with higher rates in urban compared to rural regions. Based on the Turkish Diabetes Epidemiology Study (conducted in 1997-1998), Satman et al. (28) found a prevalence of diabetes of $7.2 \%$ amongst adults of 20 years or older. Prevalence rates were considerably higher in women. In Morocco, during the year 2000 a study was conducted on a Moroccan representative sample aged 20 years or more. The prevalence of diabetes amounted to $6.6 \%$ and was similar for men and women (29). Some studies $(14,16-17)$ report a higher prevalence of diabetes mellitus type 2 among Turkish, Moroccan and Surinamese migrants in Western, industrialised countries than in their countries of origin.

The first aim of this study was to report the diabetes prevalence amongst a representative sample of Belgian adults of Turkish and Moroccan origin and to compare this prevalence rate to that of native Belgians of the same age (35- to 74-year-olds). The lower age limit is set at 35 years, because type 2 diabetes occurs predominantly at a more advanced age (over 40 years old). Although not a perfect method to discern type 1 and 2 diabetes, it is assumed not to alter the results in a significant way, as $90 \%$ of all diabetics suffer from diabetes mellitus type 2. The upper limit is set at 74 years. The second objective was to examine several of the explanations cited above. In this study, we focus on lifestyle factors - in particular excess weight/obesity and lack of physical activity - and socio-economic determinants - educational attainment and income - of diabetes patients. We took diet, albeit an important lifestyle factor 
with relation to differences in diabetes prevalence, only indirectly into account by excess weight/obesity, as the indicators constructed using the HIS 97-01-04 appeared inadequate.

\section{Methods}

\section{Data}

Both objectives were examined using the Belgian Health Interview Surveys of 1997, 2001 and 2004 (HIS 97-01-04). The Health Interview Surveys of 1997, 2001 and 2004 were carried out by the Epidemiology Unit of the Scientific Institute of Public Health. The main objective of these surveys is to give a description of the health status of the population residing in Belgium. For that purpose, a wide range of health related issues has been considered, covering five main domains: health status, health determinants, medical prevention, health consumption and health and society (30-32).

The target population of the health surveys consists of all inhabitants of Belgium, regardless of their place of birth, nationality or any other characteristic. To cover this target population as completely as possible, a random sample was drawn out of the National Register. However, the population studied does not cover the target population completely. Certain categories of persons, such as illegal refugees, homeless people, diplomats ... are not listed in the National Register. Thus, only officially registered inhabitants of Belgium were eventually included. In HIS 97-01-04, a total of 37,387 respondents was reached. The nonresponse at household level amounted to $41.5 \%, 38.6 \%$ and $38.6 \%$ in 1997, 2001 and 2004 respectively. With regard to the non-response in people of Turkish and Moroccan origin, no information is available. It is however assumed that the Health Interview Surveys sketch a representative image of the health condition of the population residing in Belgium (30-32).

The research group Interface Demography pooled the Surveys in order to obtain sufficient high numbers of Belgians of Turkish and Moroccan origin. The total population of age 35-74 included in the analysis accounts for 17,947 persons (Turkish origin $\mathrm{N}=169$; Moroccan origin $\mathrm{N}=495$ ) (30-32). The older ages were excluded from the analyses, because the number of Belgians of Turkish and Moroccan origin is too small to get accurate estimates.

\section{Method}

In order to better understand the diabetes prevalence in the age group of 35- to 74-year-olds, we conducted logistic regression analyses with diabetes prevalence as the dependent variable. Initially, we included each covariate one by one. Separate regression analyses were done with age, sex and ethnic origin as independent variables. Then, the independent variables were included two by two. In a final model, age, sex and ethnic origin were all included at the same time.

To estimate the impact of socio-economic determinants and lifestyle factors upon the prevalence of diabetes, we used stepwise logistic regression with diabetes prevalence as the 
outcome variable. First, we introduced indicators of socio-economic status, corpulence and physical activity separately. In subsequent models, all combinations of the different indicators were examined to estimate their net effects on the diabetes prevalence. Statistical analyses were executed by means of the SPSS 15.0 software.

The model underlying these analyses is that ethnic differences in the prevalence of diabetes in Belgium can be partially explained by socio-economic and lifestyle differences between the ethnic communities. However, the influence of socio-economic determinants on diabetes is not direct, but mediated by other factors. In this study, we examine if the influence of socioeconomic factors on the prevalence of diabetes is mediated by lifestyle factors. We remark that, although the data at our disposal - the Belgian Health Interview Surveys - are crosssectional, the (causal) direction of the association between type 2 diabetes mellitus and socio-economic factors can logically be deduced. For example, as type 2 diabetes occurs predominantly at an advanced age, educational attainment precedes this type of diabetes and the relation thus goes from educational level to type 2 diabetes (33).

Operational definition of the variables

Type 2 diabetes

The variable 'type 2 diabetes' is a dummy variable with the categories no diabetes $(0)$ and diabetes (1). An important remark is that it concerns self-reported diabetes. This selfreporting leads to an underestimation of the actual diabetes prevalence, since one third to half of all diabetics are unaware of the fact that they suffer from diabetes. In order to exclude type 1 diabetes at younger ages, we selected the age group of 35-year-olds and older. This is a relatively crude, but nonetheless effective way of focussing on type 2 diabetes, particularly because the proportion of type 2 diabetes in the total diabetes prevalence is estimated at $90 \%$ (1). This insulin resistant form occurs predominantly at an advanced age (over 40 years old). However, it is assumed that this disease will manifest itself in middle-aged adults because of the increased prevalence of excess weight (1). Some authors also report an earlier onset in 'newly westernised populations' $(14,25,34)$. Therefore, the lower limit is set at 35 years. The upper limit is 74 years, because the number of Belgians of Turkish and Moroccan origin of 74 years or older is too small.

\section{Ethnic origin}

To get the largest possible number of Belgians of Turkish and Moroccan origin in the sample, we used a criterion that maximises their proportion. Each member of a household, where one person had the Turkish (Moroccan) nationality or was born in Turkey (Morocco), was considered as being of Turkish (Moroccan) origin. The variable 'ethnic origin' is a categorical variable with four categories: Belgian origin (1); Turkish origin (2); Moroccan origin (3); residual category (4). 'Belgian origin' was taken as the reference modality. The residual category was excluded from our analyses. 
Age

We used the variable 'age in years'. We did not subdivide age into categories, since the prevalence of diabetes changes continuously with age in the group studied (35- to 74-yearolds). We also 'centred' age, by extracting 35-year-olds, so that the intercept would have a more meaningful interpretation. An important remark is that, by pooling the three Belgian Health Interview Surveys, we bring different birth cohorts together.

\section{Sex}

'Sex' is a dummy variable with the modalities man (0) and woman (1). 'Man' was chosen as the reference category.

\section{Socio-economic determinants}

We used the variables 'educational attainment' and 'income' as socio-economic determinants. These variables are correlated (Kendall's tau is 0.326 and Spearman's rho amounts to 0.387 ), but measure different aspects of socio-economic status.

For the variable 'educational attainment', we used the ISCED-classification. This categorical variable can acquire the following modalities: no diploma / primary education (1); lower secondary education / special secondary education (2); higher secondary education (3); higher education (4). With regard to type 2 diabetes in the age group of 35- to 74-year-olds, there is an 'educational gradient'. Persons with a lower educational level have a greater risk of diabetes than persons with a higher educational attainment. The group with the highest diabetes prevalence - no diploma / primary education - was chosen as the reference modality.

The variable '(equivalent) income' consists of the following categories: less than 750 euros (1); 750 to 1,000 euros (2); 1,000 to 1,500 euros (3); 1,500 to 2,500 euros (4); more than 2,500 euros (5). To calculate this variable the modified OECD-scale was used (35). Here again, socio-economic differences in diabetes prevalence were found. The group with the highest diabetes prevalence -750 to 1,000 euros - was taken as the reference category.

\section{Lifestyle factors}

\section{Excess weight/obesity}

We used the variable 'body mass index' (BMI) as an operational definition of the concept 'excess weight/obesity'. People with BMI of 25 or more are defined as overweight, people with $\mathrm{BMI}$ of 30 or more are considered obese. In order for the intercept to have a more meaningful interpretation, this variable was centred ('BMI - 25.77').

A limitation of the variable 'body mass index' is that it is based on reported height and weight and therefore less reliable compared to measured data (36-37). The use of self-reported data results in an underestimation of $\mathrm{BMI}(37)$. A second limitation of our data is the use of $\mathrm{BMI}$ as the sole criterion of excess weight. According to a number of studies $(1,5,38)$, abdominal obesity is, apart from overall excess weight, an independent risk factor in type 2 diabetes. 
The accumulation of intra-abdominal or visceral fat is strongly associated with type 2 diabetes (5).

\section{Physical activity}

We measured the concept of 'physical activity' by the variable 'population at risk due to a lack of leisure time physical activity' as defined in the manual of the Health Interview Surveys (35). We relabelled this variable as 'lack of (leisure time) physical activity'. This is a dummy variable with the categories: weekly physically active (0) and sedentary (1). The category 'weekly physically active' was taken as the reference modality.

A restriction of this indicator is that it does not take physical exercise during professional activity into account. As a consequence, it is strongly socio-economically related. Persons with a lower education more often have sedentary leisure activities. A second limitation of the variable 'lack of (leisure time) physical activity' is that it is culturally related. In the Turkish and Moroccan culture, there is no tradition of leisure time physical activity, especially not for women (28).

\section{Results}

We start by comparing the prevalence of diabetes in the Turkish and Moroccan communities in Belgium with the prevalence in native Belgians. Subsequently, we examine a number of explanations for the higher diabetes prevalence in Belgians of Turkish and Moroccan origin. The focus will be on lifestyle factors - excess weight/obesity and lack of physical activity and socio-economic determinants - educational attainment and income.

\section{Diabetes prevalence}

As expected, figure 1 shows that the prevalence of diabetes in our sample increases with age $(1,5)$. At age 25 , the risk of diabetes in native Belgians is 0.006 . In 25-year-old Belgians of Turkish origin, the risk of diabetes is 0.023 . In Belgians of Moroccan origin of the same age, the risk of diabetes amounts to 0.017 . At age 70 , the mean diabetes probability has increased to $0.122,0.362$ and 0.297 in native Belgians, Belgians of Turkish origin and Belgians of Moroccan origin respectively. The diabetes prevalence is higher at all ages in Belgians of Turkish and Moroccan origin than in native Belgians (14-15; 19-21). Finally, figure 1 reveals that type 2 diabetes has an earlier onset in the Turkish and Moroccan communities in Belgium. Kriegsman et al. (14) also report a difference in mean age between the patients in their inquiry. Dutch patients were older than Turkish and Moroccan patients. According to Baschetti (25) and Østbye et al. (34), type 2 diabetes occurs at an earlier age in newly westernised populations. 
Figure 1. Diabetes prevalence as a function of age and ethnic origin

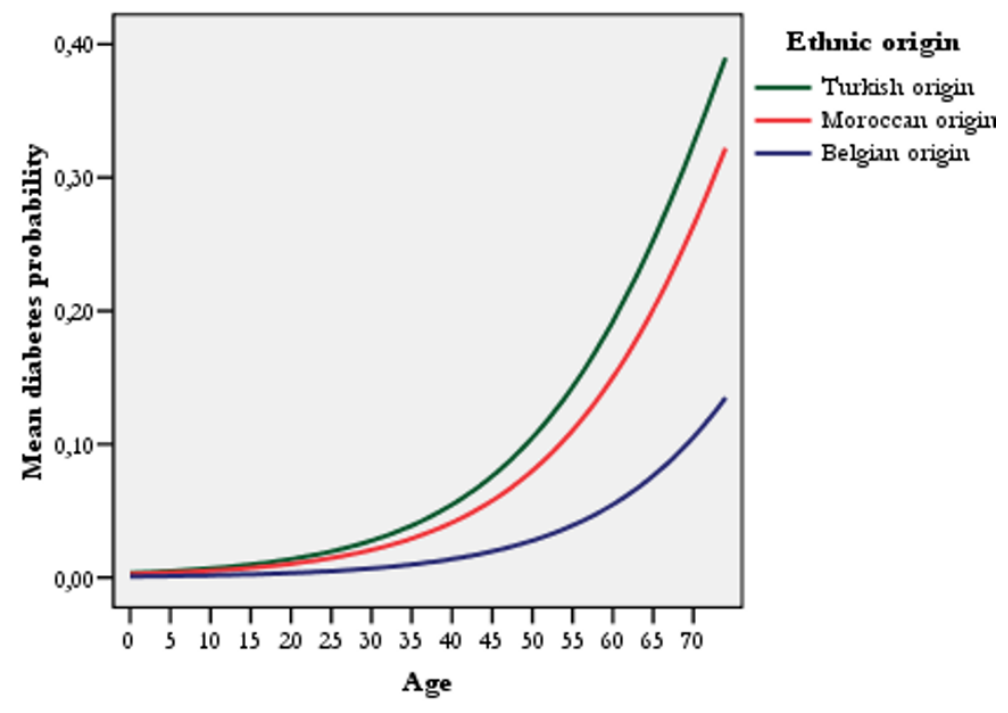

Table 1 gives an overview of the results of the logistic regression analyses of the prevalence of diabetes by age, sex and ethnic origin (age group of 35- to 74-year-olds).

Models 1 and 2 are additive models. Model 1 shows us that the risk of diabetes increases with age. As appears from model 2, Belgians of Turkish and Moroccan origin have a higher risk of type 2 diabetes. The odds ratio for Turkish versus Belgian subjects amounts to 4.573 . For Moroccan subjects, the odds ratio is 3.106 .

In model 3, we included the interaction term 'ethnic origin*sex'. The inclusion of this interaction term leads to a significant improvement of the model fit. As appears from the parameter estimates of model 3, the mean diabetes probability in native Belgians is lower in women than in men. In the Turkish and Moroccan communities on the other hand, women are at a higher risk. In men as well as in women, the risk of type 2 diabetes is higher in the Turkish and Moroccan communities than in the native Belgian community, but the differences are more pronounced in women. In the age group of 35- to 74-year-olds, the prevalence of type 2 diabetes amounts to $5.0 \%, 5.8 \%$ and $6.5 \%$ in men of Belgian, Turkish and Moroccan origin respectively. In the same age group, the prevalence of diabetes in women of Belgian origin is $4.3 \%$. In the Turkish and Moroccan communities in Belgium, women are at a higher risk (18.7\% and $11.9 \%$ respectively).

\section{Risk factors}

As stated above, based on HIS 97-01-04 we found a higher diabetes prevalence in adults of the Turkish and Moroccan community in Belgium than amongst native Belgians. In this section, we examine explanations that attribute the higher diabetes prevalence amongst 'recently westernised populations' to socio-economic factors and lifestyle patterns, but first 
we discuss the distribution of these risk factors - educational attainment, income, BMI and lack of physical activity - in the age group of 35- to 74-year-olds.

The distribution of risk factors

As regards socio-economic determinants, 35- to 74-year-old men and women of Turkish and Moroccan origin are generally lower educated than native Belgian men and women of the same age group and they also more often have a lower income than native Belgians.

With regard to lifestyle factors, there is no significant difference in excess weight and obesity between men of Turkish and Moroccan origin and native Belgian men. In women on the other hand, the prevalence of excess weight and obesity is higher in the Turkish and Moroccan communities. For example, of the native Belgian women $43.2 \%$ are overweight, as opposed to $72.2 \%$ of the women of Turkish origin and $68.8 \%$ of the women of Moroccan origin. When we focus on the variable 'lack of (leisure time) physical activity', Turkish and Moroccan men as well as women more often have sedentary leisure activities than Belgian men and women (table 2).

\section{Socio-economic determinants}

In this section, we examine to what extent socio-economic factors can explain the ethnic differences in diabetes prevalence. Analyses are presented for men and women separately.

\section{Educational attainment}

Table 3 and 4 give an overview of the diabetes prevalence by age, ethnic origin, socioeconomic determinants and lifestyle factors for men and women respectively. In both men and women, there are ethnic differences in the prevalence of diabetes, although the ethnic differences in the prevalence of type 2 diabetes are smaller in men (table 3 and 4, model 1 ). The odds ratio for Turkish versus Belgian men is 1.714. For Moroccan versus Belgian men, the odds ratio amounts to 1.990 . For Turkish versus Belgian women and Moroccan versus Belgian women, the odds ratios are 8.608 and 4.696 respectively.

Accounting for educational attainment, the ethnic differences in the prevalence of diabetes in both men and women become smaller (table 3 and 4, model 2). A lower educational level is thus associated with the higher diabetes prevalence in Belgians of Turkish and Moroccan origin. People with a lower educational level have a greater risk of type 2 diabetes. This socio-economic gradient in the prevalence of diabetes is stronger in women than in men. This finding is in keeping with our expectations. Beck, Vanroelen and Louckx (27) also report - based on HIS 97 - a steeper socio-economic gradient in chronic morbidity in women, compared to men.

\section{Income}

Accounting for income, in men as well as in women, the ethnic differences in diabetes prevalence remain almost unaltered (table 3 and 4, model 3). Moreover, in men, the income gradient - the decreased risk of diabetes as income increases - is rather small (controlling 
Table 1. Model estimates of diabetes prevalence by age, sex, ethnic origin

and the interaction effect 'ethnic origin*sex' (men and women jointly)

\begin{tabular}{|c|c|c|c|c|c|c|c|}
\hline & & \multicolumn{6}{|c|}{ Model } \\
\hline & \multirow[b]{2}{*}{ Categories } & \multicolumn{2}{|c|}{ Model 1} & \multicolumn{2}{|c|}{ Model 2} & \multicolumn{2}{|c|}{ Model 3} \\
\hline Variables & & $e^{b}$ & $95 \% \mathrm{Cl}$ & $e^{b}$ & $95 \% \mathrm{Cl}$ & $e^{b}$ & $95 \% \mathrm{Cl}$ \\
\hline Intercept & & 0.013 & $-0.178-0.204$ & 0.012 & $-0.197-0.221$ & 0.012 & $-0.197-0.221$ \\
\hline Age $<35$ & & 1.065 & $1.058-1.073$ & 1.069 & $1.061-1.076$ & 1.069 & $1.061-1.076$ \\
\hline \multirow[t]{2}{*}{ Sex } & Man (ref.) & & & & & & \\
\hline & Woman & & & 0.881 & $0.758-1.023$ & 0.818 & $0.700-0.955$ \\
\hline \multirow[t]{3}{*}{ Ethnic origin } & Belgian (ref.) & & & & & & \\
\hline & Turkish & & & 4.573 & $2.720-7.690$ & 1.702 & 0.607 \\
\hline & Moroccan & & & 3.106 & $2.189-4.408$ & 1.978 & $1.146-3.413$ \\
\hline \multirow[t]{8}{*}{ Ethnic origin*sex } & Turkish*woman & & & & & 5.102 & $1.529-17.022$ \\
\hline & Moroccan*woman & & & & & 2.393 & $1.178-4.861$ \\
\hline & Deviance & \multicolumn{2}{|c|}{5640.207} & \multicolumn{2}{|c|}{5583.089} & \multicolumn{2}{|c|}{5569.258} \\
\hline & $\Delta \chi^{2}$ & \multicolumn{2}{|c|}{$350.488^{*}$} & \multicolumn{2}{|c|}{$57.118^{*}$} & \multicolumn{2}{|c|}{$13.831^{*}$} \\
\hline & Df & \multicolumn{2}{|c|}{1} & \multicolumn{2}{|c|}{3} & \multicolumn{2}{|c|}{2} \\
\hline & AIC & \multicolumn{2}{|c|}{5642.207} & \multicolumn{2}{|c|}{5593.089} & \multicolumn{2}{|c|}{5583.258} \\
\hline & $\mathrm{BIC}$ & \multicolumn{2}{|c|}{5659.516} & \multicolumn{2}{|c|}{5631.360} & \multicolumn{2}{|c|}{5636.838} \\
\hline & $\mathrm{N}$ & \multicolumn{2}{|c|}{15588} & \multicolumn{2}{|c|}{15588} & \multicolumn{2}{|c|}{15588} \\
\hline
\end{tabular}

$\mathrm{Cl}$ : confidence interval

${ }^{*} p<0.001$ 
Table 2. The distribution of risk factors (in \%; age group of 35- to 74-year-olds)

\begin{tabular}{|c|c|c|c|c|c|c|c|c|c|c|c|}
\hline \multirow[b]{3}{*}{ Variables } & \multirow[b]{3}{*}{ Categories } & \multicolumn{10}{|c|}{ Distribution (in \%) } \\
\hline & & \multicolumn{5}{|c|}{ Men } & \multicolumn{5}{|c|}{ Women } \\
\hline & & Belgian & Turkish & Moroccan & $\chi^{2}$ & Df & Belgian & Turkish & Moroccan & $\chi^{2}$ & Df \\
\hline \multicolumn{12}{|l|}{ Socio-economic factors } \\
\hline \multirow[t]{4}{*}{ Educational level } & No diploma/prim. ed. & 18.4 & 65.1 & 46.9 & $228.907^{*}$ & 6 & 22.3 & 82.2 & 65.9 & $354.869^{*}$ & 6 \\
\hline & Lower sec. ed. & 22.9 & 10.8 & 16.3 & & & 24.4 & 8.2 & 15.2 & & \\
\hline & Higher sec. ed. & 29.4 & 14.5 & 22.2 & & & 27.3 & 5.5 & 10.4 & & \\
\hline & Higher ed. & 29.2 & 9.6 & 14.6 & & & 26.0 & 4.1 & 8.5 & & \\
\hline \multirow[t]{5}{*}{ Income } & $<750 €$ & 5.3 & 11.5 & 9.8 & $70.325^{\star}$ & 8 & 7.5 & 12.3 & 10.8 & $37.370^{*}$ & 8 \\
\hline & $750-1000 €$ & 8.2 & 16.7 & 15.4 & & & 11.1 & 13.7 & 18.8 & & \\
\hline & $1000-1500 €$ & 23.9 & 29.5 & 27.4 & & & 24.9 & 26.0 & 23.9 & & \\
\hline & $1500-2500 €$ & 36.8 & 30.8 & 39.3 & & & 34.0 & 35.6 & 37.6 & & \\
\hline & $>2500 €$ & 25.8 & 11.5 & 8.1 & & & 22.5 & 12.4 & 8.9 & & \\
\hline \multicolumn{12}{|l|}{ Lifestyle factors } \\
\hline Excess weight & & 59.7 & & & $1.194 n s$ & 2 & 43.2 & 72.2 & 68.8 & $76.731^{*}$ & 2 \\
\hline Obesity & & 15.5 & & & $0.194 n s$ & 2 & 14.7 & 37.5 & 33.2 & $80.922^{*}$ & 2 \\
\hline $\begin{array}{l}\text { Lack of physical activ- } \\
\text { ity }\end{array}$ & & 28.2 & 65.5 & 47.9 & $70.295^{\star}$ & 2 & 35.9 & 72.0 & 63.6 & $76.978^{*}$ & 2 \\
\hline
\end{tabular}

${ }^{*} p<0.001$

ns: not significant 
Table 3. Model estimates of diabetes prevalence by age, ethnic origin and socio-economic determinants and lifestyle factors (men)

\begin{tabular}{|c|c|c|c|c|c|c|c|c|c|c|c|}
\hline \multirow[b]{3}{*}{ Variables } & \multirow[b]{3}{*}{ Categories } & \multicolumn{10}{|c|}{ Model } \\
\hline & & \multicolumn{2}{|c|}{ Model 1} & \multicolumn{2}{|c|}{ Model 2} & \multicolumn{2}{|c|}{ Model 3} & \multicolumn{2}{|c|}{ Model 4} & \multicolumn{2}{|c|}{ Model 5} \\
\hline & & $e^{b}$ & $95 \% \mathrm{Cl}$ & $e^{b}$ & $95 \% \mathrm{Cl}$ & $e^{b}$ & $95 \% \mathrm{Cl}$ & $e^{b}$ & $95 \% \mathrm{Cl}$ & $e^{b}$ & $95 \% \mathrm{Cl}$ \\
\hline Intercept & & 0.012 & $-0.262-0.286$ & 0.015 & $-0.346-0.375$ & 0.015 & $-0.432-0.463$ & 0.009 & $-0.310-0.328$ & 0.010 & $-0.406-0.427$ \\
\hline Age $<35$ & & 1.070 & $1.059-1.080$ & 1.067 & $1.056-1.078$ & 1.068 & 1.056-1.079 & 1.070 & $1.058-1.082$ & 1.069 & $1.056-1.081$ \\
\hline \multirow[t]{3}{*}{ Ethnic origin } & Belgian (ref.) & & & & & & & & & & \\
\hline & Turkish & 1.714 & $0.610-4.819$ & 1.536 & $0.542-4.354$ & 1.788 & $0.629-5.079$ & 1.121 & $0.256-4.906$ & 1.061 & $0.241-4.671$ \\
\hline & Moroccan & 1.990 & $1.151-3.442$ & 1.840 & $1.054-3.212$ & 1.808 & $1.002-3.264$ & 1.868 & $0.953-3.662$ & 1.805 & $0.915-3.558$ \\
\hline \multicolumn{12}{|l|}{ Lifestyle factors } \\
\hline BMI $<25.77$ & & & & & & & & 1.095 & $1.071-1.120$ & 1.094 & $1.069-1.119$ \\
\hline \multirow[t]{2}{*}{ Physical activity } & $\begin{array}{l}\text { Weekly physically } \\
\text { active (ref.) }\end{array}$ & & & & & & & & & & \\
\hline & Sedentary & & & & & & & 1.423 & $1.121-1.805$ & 1.395 & 1.098-1.772 \\
\hline \multicolumn{12}{|c|}{ Socio-economic factors } \\
\hline \multirow[t]{4}{*}{$\begin{array}{l}\text { Educational } \\
\text { attainment }\end{array}$} & $\begin{array}{l}\text { No diploma/ } \\
\text { prim.ed. (ref.) }\end{array}$ & & & & & & & & & & \\
\hline & Lower sec. Ed. & & & 1.061 & $0.797-1.413$ & & & & & 1.020 & $0.743-1.401$ \\
\hline & Higher sec.ed. & & & 0.778 & $0.577-1.049$ & & & & & 0.878 & $0.635-1.213$ \\
\hline & Higher ed. & & & 0.716 & $0.524-0.977$ & & & & & 0.807 & $0.574-1.135$ \\
\hline \multirow[t]{5}{*}{ Income } & $<750 €$ & & & & & 1.068 & $0.655-1.741$ & & & & \\
\hline & $750-1000 €$ (ref.) & & & & & & & & & & \\
\hline & $1000-1500 €$ & & & & & 0.861 & $0.596-1.244$ & & & & \\
\hline & $1500-2500 €$ & & & & & 0.774 & $0.536-1.116$ & & & & \\
\hline & $>2500 €$ & & & & & 0.733 & $0.480-1.121$ & & & & \\
\hline
\end{tabular}




\begin{tabular}{|l|l|c|c|c|c|c|}
\hline \multicolumn{2}{|l|}{} & Deviance & 2820.730 & 2811.812 & 2531.701 & 2338.702 \\
\hline & $\Delta \chi^{2 *}$ & $199.773^{* *}$ & $208.691^{* *}$ & $189.429^{* *}$ & 2341.165 \\
\hline & Df & 3 & 6 & 7 & $244.291^{* *}$ \\
\hline & AIC & 2828.730 & 2825.812 & 2547.701 & $2673^{\star *}$ \\
\hline & BIC & 2856.489 & 2874.391 & 2602.274 & 2353.165 \\
\hline & N & 7630 & 7630 & 6779 & 2417.862 \\
\hline
\end{tabular}

* Deviances are always compared to the respective intercept model

${ }^{* *} p<0.001$

Table 4. Model estimates of diabetes prevalence by age, ethnic origin and socio-economic determinants and lifestyle factors (women)

\begin{tabular}{|c|c|c|c|c|c|c|c|c|c|c|c|}
\hline \multirow[b]{3}{*}{ Variables } & \multirow[b]{3}{*}{ Categories } & \multicolumn{10}{|c|}{ Model } \\
\hline & & \multicolumn{2}{|r|}{ Model 1} & \multicolumn{2}{|r|}{ Model 2} & \multicolumn{2}{|r|}{ Model 3} & \multicolumn{2}{|r|}{ Model 4} & \multicolumn{2}{|c|}{ Model 5} \\
\hline & & $e^{b}$ & $95 \% \mathrm{Cl}$ & $e^{b}$ & $95 \% \mathrm{Cl}$ & $e^{b}$ & $95 \% \mathrm{Cl}$ & $e^{b}$ & $95 \% \mathrm{Cl}$ & $e^{b}$ & $95 \% \mathrm{Cl}$ \\
\hline Intercept & & 0.010 & $-0.276-0.296$ & 0.018 & $-0.343-0.380$ & 0.014 & $-0.419-0.448$ & 0.007 & $-0.343-0.357$ & 0.010 & $-0.430-0.450$ \\
\hline Age $<35$ & & 1.068 & $1.057-1.079$ & 1.058 & $1.046-1.069$ & 1.061 & $1.049-1.073$ & 1.060 & $1.048-1.073$ & 1.055 & $1.042-1.068$ \\
\hline \multirow[t]{3}{*}{ Ethnic origin } & Belgian (ref.) & & & & & & & & & & \\
\hline & Turkish & 8.608 & $4.583-16.166$ & 6.007 & $3.161-11.414$ & 7.826 & $4.065-15.064$ & 8.243 & $3.855-17.622$ & 6.872 & $3.163-14.930$ \\
\hline & Moroccan & 4.696 & $2.960-7.450$ & 3.497 & $2.172-5.632$ & 4.687 & $2.931-7.495$ & 2.554 & $1.328-4.913$ & 2.215 & $1.140-4.302$ \\
\hline \multicolumn{12}{|l|}{ Lifestyle factors } \\
\hline $\mathrm{BMI}<25.77$ & & & & & & & & 1.128 & $1.106-1.151$ & 1.123 & $1.100-1.146$ \\
\hline \multirow[t]{2}{*}{ Physical activity } & $\begin{array}{l}\text { Weekly physically } \\
\text { active (ref.) }\end{array}$ & & & & & & & & & & \\
\hline & Sedentary & & & & & & & 2.019 & $1.564-2.606$ & 1.930 & $1.493-2.495$ \\
\hline
\end{tabular}




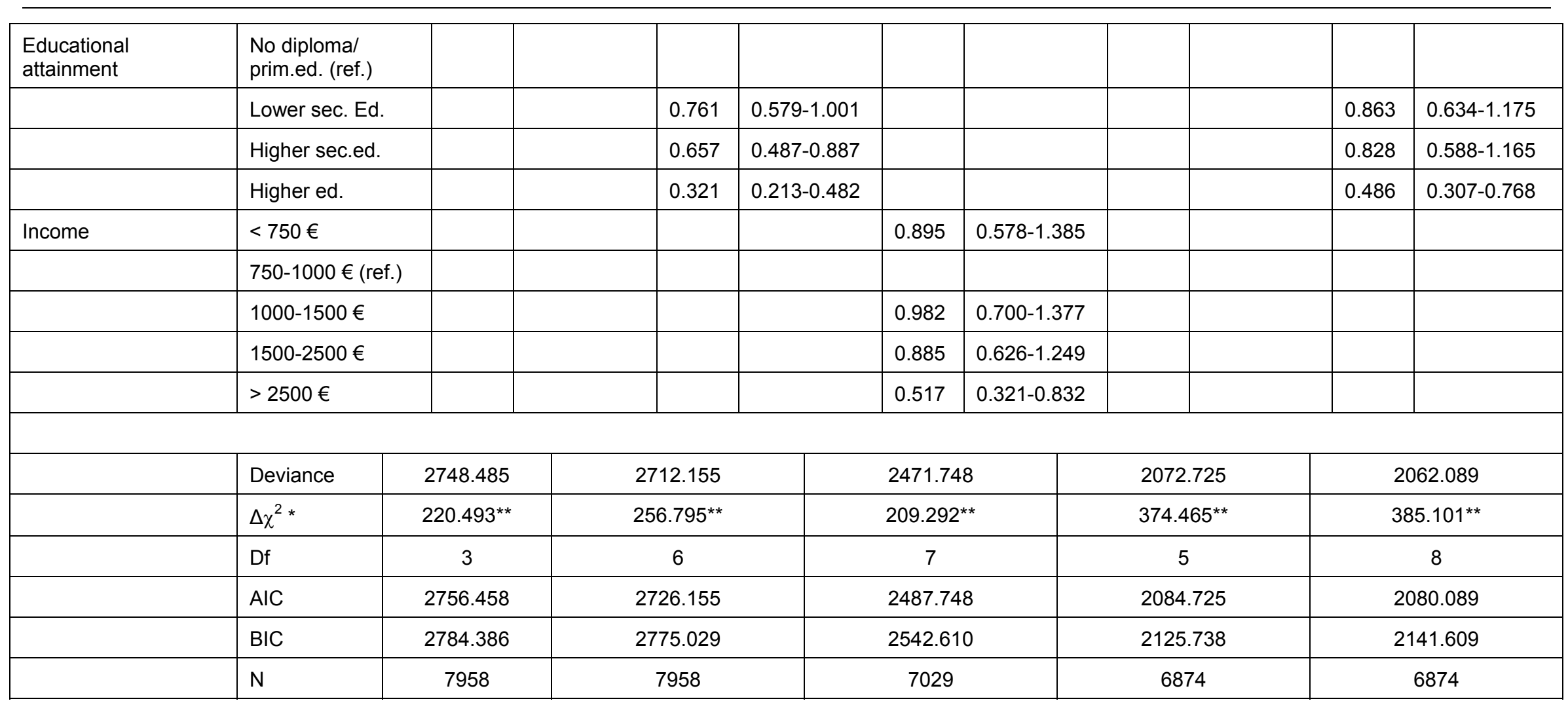

* Deviances are always compared to the respective intercept model

${ }^{* *} p<0.001$ 
for age). In women, the gradient is a bit steeper (controlling for age), but the risk of diabetes differs only substantially from the reference category in people with an income of more than 2,500 euros. Yet, this does not necessarily mean that income is not an important socioeconomic determinant in the prevalence of diabetes. It simply implies that the relation between income and diabetes is probably more complex and differs according to ethnic origin ${ }^{2}$. However, we did not have enough statistical power to further explore the relationship between income and diabetes. We therefore excluded the variable 'income' from further analyses.

\section{Lifestyle factors}

Next to socio-economic determinants, lifestyle plays an important part in the development of type 2 diabetes. In this study, we explore if the lifestyle factors 'excess weight/obesity' and 'lack of physical activity' explain community differences in the prevalence of diabetes. As lifestyle factors are strongly gender-related (27), we present our analyses for men and women separately.

First, we conducted analyses with BMI and lack of physical activity separately (results not presented). When the variable 'lack of (leisure time) physical activity' is included in the analyses, the ethnic differences in the prevalence of diabetes in men are strongly reduced. In women, the differences in diabetes prevalence between the ethnic communities in Belgium persist, after controlling for 'lack of physical activity'. The more sedentary leisure lifestyle of Turkish and Moroccan women does not explain their higher risk of diabetes compared to Belgian women. In women, differences in the prevalence of type 2 diabetes between the different communities get particularly smaller, accounting for BMI. The higher diabetes prevalence in women of Turkish and Moroccan origin is thus associated with their higher mean BMI (Turkish origin: $\mathrm{BMI}=28.678$, Moroccan origin: $\mathrm{BMI}=27.468$; Belgian origin: $\mathrm{BMI}$ $=25.130$ ). In men on the other hand, the ethnic differences in the prevalence of diabetes stay approximately the same, accounting for BMI. This is in line with our expectations, as there are no significant differences in excess weight/obesity in men (table 2).

Then, we inserted both lifestyle factors in the analyses. As mentioned above, the ethnic differences in the prevalence of diabetes in men are strongly reduced, when the variable 'lack of (leisure time) physical activity' is included. Inserting both lifestyle factors, the community

\footnotetext{
2 When we examined this relationship by means of crosstabs, we found that a lower income is associated with a higher prevalence of type 2 diabetes in 35- to 74-year-old native Belgian men $\left(\chi^{2}=38.982(p<0.001)\right)$. In Belgian men of Turkish and Moroccan origin on the other hand, we found no statistically significant association between income and diabetes prevalence. Chi-squares are $2.828(p=0.587)$ and $8.347(p=0.080)$ respectively. These results are, however, not 'robust', as more than $20 \%$ of the crosstab cells have expected counts less than 5 . In native Belgian women as well as in Belgian women of Moroccan descent, a lower income is associated with a higher prevalence of type 2 diabetes $\left(\chi^{2}=48.807(p<0.001)\right.$ and $\chi^{2}=9.942(p<0.05)$ respectively). In Belgian women of Turkish origin, we found no statistically significant association between income and diabetes prevalence $\left(\chi^{2}=2.426(p=0.656)\right)$. As in Belgian men of Turkish and Moroccan origin, it is difficult to draw conclusions from the association between income and diabetes prevalence in Belgian women of Turkish and Moroccan origin, because the expected counts in the cells of the crosstabs are very low.
} 
differences in the prevalence of diabetes in men remain strongly reduced (table 3, model 4). In women, the ethnic differences in diabetes prevalence remain high, accounting for both lifestyle factors (table 4, model 4).

Lifestyle factors and educational attainment

In this section, we explore if the socio-economic impact on the prevalence of diabetes runs through lifestyle factors.

Men - The effect of educational level on the risk of type 2 diabetes in men becomes smaller, when the variables BMI and lack of physical activity are inserted in the analyses (table 3 , model 2 and 5). Therefore, we may suppose that the influence of educational attainment on diabetes prevalence is partially mediated by these lifestyle factors.

After controlling for educational attainment, the ethnic differences in the prevalence of diabetes in men become even smaller. This implies that, next to lifestyle effects, there is an additional effect of educational level on the ethnic differences in the prevalence of diabetes. On the other hand, accounting for educational attainment, the influences of BMI and lack of leisure time physical activity on diabetes persist (table 3, model 4 and 5).

Women - When BMI and lack of physical activity are included in the analyses, the effect of educational level on the risk of diabetes becomes a bit smaller (table 4, model 2 and 5). In women too, the influence of educational level on the risk of diabetes is likely to run partially through the lifestyle factors BMI and lack of (leisure time) physical activity, although other factors - not inserted in these analyses - mediate the relationship between educational level and the prevalence of diabetes. Moreover, after controlling for educational level, the ethnic differences in the prevalence of diabetes become smaller. Yet, the odds ratios for Turkish versus Belgian and for Moroccan versus Belgian women are still rather high (6.872 and 2.215 respectively). Thus, in women, other determinants play an important part in the ethnic differences in diabetes prevalence (cf discussion).

\section{Discussion}

\section{Diabetes prevalence}

Based on HIS 97-01-04, in native Belgian men a prevalence of type 2 diabetes of $5.0 \%$ was found. In 35- to 74-year-old men of Turkish and Moroccan origin, the prevalence amounts to $5.8 \%$ and $6.5 \%$ respectively. In the same age group, the prevalence of diabetes in women of Belgian origin is $4.3 \%$. In the Turkish and Moroccan communities in Belgium, the diabetes prevalence rates are strikingly higher. $18.7 \%$ and $11.9 \%$ of the women of Turkish and Moroccan origin respectively suffer from type 2 diabetes. The findings of this study are consistent with those of other studies on diabetes amongst 'recently westernised populations' (12-19). Comparing these prevalence rates with those in Turkey and Morocco $(7.2 \%$ and $6.6 \%$ respectively in the age group of 20 -year-olds or older), we may assume that the prevalence of type 2 diabetes in Belgians of Turkish and Moroccan origin is considerably higher, at 
least in women. This assumption is reinforced by the fact that the Turkish and Moroccan surveys are based on measured data, while the Belgian HIS rely on self-reported information. Therefore, we may assume an underestimation of the prevalence of type 2 diabetes by at least one third in the Belgian sample (cf supra).

\section{Risk factors}

In this study, we found evidence that BMI, lack of leisure time physical activity and educational attainment play an important part in the higher diabetes prevalence in the Turkish and Moroccan communities in Belgium. In both men and women, the inclusion of educational attainment in the analyses reduces the ethnic differences in diabetes prevalence. Lifestyle factors are also crucial in broadening our understanding of the community differences in the prevalence of diabetes. In men, the lifestyle variable 'a lack of physical activity' appeared to play an important part in the higher mean diabetes probability in men of Turkish and Moroccan origin. In women, the higher risk of type 2 diabetes amongst women of the Turkish and Moroccan communities in Belgium is particularly associated with their higher mean BMI. In men as well as in women, the influence of educational attainment on the risk of type 2 diabetes becomes smaller, when the lifestyle factors BMI and lack of (leisure time) physical activity are included in the analyses. In both men and women, the results are thus in line with the underlying model that socio-economic differences in the prevalence of diabetes are likely to be mediated by lifestyle factors. In women however, other determinants - other than BMI, lack of leisure time physical activity, educational attainment and income - play an important part in the ethnic differences in diabetes prevalence, as the odds ratios for Turkish versus Belgian and Moroccan versus Belgian women remain high when controlling for the abovementioned determinants.

Thus, for women, possible explanations have to be sought elsewhere. The migration experience, foetal conditions, dietary habits, psychosocial stress, parity (and gestational diabetes) and a higher lead exposure are presented as possible explanations for this ethnic gap in type 2 diabetes. These explanations are neither exhaustive nor mutually exclusive.

As we may assume that the prevalence of type 2 diabetes is higher in Belgians of Turkish and Moroccan origin than in Turks and Moroccans living in Turkey and Morocco respectively, it might be hypothesised that the migration experience and the associated rapid changeover to a western lifestyle (low level of physical activity, calorie-rich diet ...; often accompanied by a high rate of weight gain) contribute to the higher diabetes prevalence in Belgian women of Turkish and Moroccan origin. A high rate of weight gain is assumed to be an independent risk factor of type 2 diabetes, irrespective of obesity $(34,39)$. Turkish and Moroccan migrants generally originate from specific rural regions in Turkey and Morocco respectively (40). Both men and women were used to perform physically taxing labour, especially in agriculture. It might be hypothesized that women, coming from these rural areas in Turkey or Morocco, experience the most sweeping lifestyle change, as the men generally exert physically taxing jobs in Belgium while the women become housewives and switch to a predominantly sedentary existence (28). This hypothesis is further supported by the fact that there are regional 
differences in the prevalence of type 2 diabetes in Turkey and Morocco. In these countries, the diabetes rate is substantially higher in urban areas than in rural areas. This urban-rural differential in diabetes prevalence is likely to be associated with different lifestyles. Among urban populations, a sedentary lifestyle and obesity are more prevalent (28-29).

The 'foetal origins hypothesis' might provide additional insight in the relatively high diabetes prevalence in Belgian women of Turkish and Moroccan origin. This hypothesis is based on the observation that a low birth weight is associated with a higher risk of type 2 diabetes. In the last two decades, two (partially) competing 'foetal origins hypotheses' have been formulated to account for this association, namely the 'thrifty phenotype hypothesis' and the 'foetal insulin hypothesis' (41). According to the 'thrifty phenotype hypothesis', in utero and early post-natal malnutrition are detrimental to the development and function of the $\beta$-cells of the islets of Langerhans. Such structural and functional defects predispose people to the later development of type 2 diabetes. Whilst these early changes powerfully determine susceptibility, additional factors, such as obesity and physical inactivity, also play a part in the development of type 2 diabetes mellitus (42). The essence of the 'foetal insulin hypothesis' is that the association between low birth weight and type 2 diabetes is at least partially caused by an insulin resistant-prone genotype. Genetic factors increase insulin resistance in utero and may produce two phenotypes: a growth-restricted infant and an adult with insulin resistance and increased risk of type 2 diabetes (43). The 'thrifty phenotype hypothesis' might at least partly explain why Belgian women of Turkish and Moroccan origin are at a higher risk of type 2 diabetes. As almost $90 \%$ of the 35- to 74-year-old women of the Turkish and Moroccan communities in our sample are born and have spent a part of their childhood in their respective mother countries where the risk of poor nutrition in childhood was higher, the 'thrifty phenotype' hypothesis might provide a partial explanation for their relatively high diabetes prevalence, especially when they also experience a rapid changeover to a western lifestyle.

Dietary habits may play an important part in the ethnic differences in diabetes prevalence in women. With regard to nutritional behaviour, the habits of Turkish and Moroccan migrants seem to be healthier at some points and less healthy in other aspects (44-45). In general, their diet consists of more fruit and vegetables and less saturated fat, but their eating pattern is very irregular. In Ghent, a study about dietary habits in Turkish diabetes patients was conducted. Not only the irregular eating pattern is remarkable, but Belgians of Turkish origin also have a hot meal twice a day, often having white bread with it. That results in the consumption of a great amount of carbohydrates (22). Malki and Waterval (45) describe the same pattern in Dutch Moroccans. Moreover, they state that the irregular eating pattern - eating when hungry - makes Dutch people of Moroccan origin eat bigger helpings. Another often cited dietary explanation for the relatively high diabetes prevalence in women of Turkish and Moroccan origin is unbalanced eating habits (23).

Additionally to diet, psychosocial stress may also be an important factor in the high prevalence of diabetes in women of both Turkish and Moroccan origin. Already in the $17^{\text {th }}$ century, the relationship between stress and diabetes was proposed by Thomas Willis (8). Today, the 
relationship between blood glucose level and acute stress situations is demonstrated in a number of studies (6). Less is known about the influence of chronic stress on diabetes (8). Björntorp (7) hypothesized that psychosocial stress with a defeatist or helpless reaction leads to 'hypothalamic arousal', which is expressed as a high rate of secretion of cortisol and a low rate of secretion of sex steroids. This hormonal imbalance directs storage fat to visceral adipose tissue (46). This theory of Björntorp was investigated in the Hoorn study (47). In this study, carried out in the Dutch city of Hoorn, a high number of major stressful life events during the past five years was associated with a higher prevalence of previously unknown diabetes. This association persisted after adjustment for age, sex, lifestyle variables and socio-economic indicators. Moreover, stressful life events were positively related to visceral adiposity. However, in contrast with Björntorp's theory, waist-to-hip ratio did not mediate the association between psychological stress and type 2 diabetes. As stated above, another important element in the theory of Björntorp is the 'defeatist' or 'helplessness' reaction. In individuals, who are biologically or otherwise at risk to develop diabetes, stress is not sufficient to 'cause' diabetes, but stress coupled with a feeling of 'loss of control' may lead to diabetes. This is in line with more recent research, where Swedish women experienced a higher diabetes risk only if they were exposed to both low decision latitude and low sense of coherence (48). Furthermore, an increase in serum cortisol and a decrease in sex steroids affect the insulin activity and may cause hyperglycaemia (7). To conclude, psychosocial stress is repeatedly cited as an important risk factor in the higher diabetes prevalence amongst 'recently westernised populations' (13-14, 16-17). 'Recently westernised populations', like Belgians of Turkish and Moroccan origin, often live in a country that still is foreign to them. That may add to psychosocial stress. Moreover, their generally lower socioeconomic status, discrimination experiences, and perceived lack of social support may also cause stress. Finally, migration and the consequences of migration are often very stressing $(10,49)$.

Next to the migration experience, dietary habits and psychosocial stress, pregnancy - and in particular gestational diabetes - may play an important part in the higher diabetes prevalence in women of Turkish and Moroccan origin. According to Satman et al. (28), obesity and glucose intolerance become common in women beyond childbearing age in Turkey. It might be hypothesized that Turkish and Moroccan women are already overweight/obese before they get pregnant. Consequently, during the pregnancy period, they are at a higher risk of gestational diabetes (50). Moreover, after giving birth to one or more children, they never lose their excess weight. Both excess weight and gestational diabetes are independent risk factors of type 2 diabetes $(1,4-5)$. Additionally, parity is higher in the Turkish and Moroccan communities than in the Belgian community (51). A cycle, in which excess weight/obesity, pregnancy and gestational diabetes reinforce one another and cause type 2 diabetes mellitus, could appear. Nevertheless, we were not able to test this hypothesis as 'parity' was not questioned in HIS 97-01-04. Therefore, we suggest the inclusion of this variable in future health surveys. 
Next to the above explanations, it might be hypothesized that a higher lead exposure could be (partially) responsible for the relatively high diabetes prevalence in Belgian women of Turkish and Moroccan origin. Standard lead sources are tap water, paint chips and dust; sources of lead, which are mostly found in old, ramshackle houses (52). Due to their generally lower socio-economic status, Belgians of Turkish and Moroccan origin are more likely to live in such dwellings. Other - less standard - sources of lead intoxication are traditional medicines (especially some herbs) (53) and metallic teapots, traditionally used by North African populations (54). In the Turkish and Moroccan communities, traditional healers are more often consulted than among the native Belgian population. Moreover, they have a 'culture' of tea sipping (54-55). Many negative health consequences ensue from (high) lead exposure. In adults, a positive association of lead exposure with blood pressure - an independent risk factor of diabetes type 2 - has been identified in a number of studies in different settings. Schwartz (56) and Navas-Acien et al. (57) conclude that the evidence is sufficient to infer a causal relationship between lead exposure with and hypertension. Moreover, exposure to lead is also positively associated with coronary heart disease and stroke (57). Bener et al. (58) found a positive correlation between blood lead levels and fasting serum glucose, indicating that lead exposure may be associated with diabetes. Afridi et al. (59) recently demonstrated that the concentration of the toxic metals arsenic, cadmium and lead is higher in samples of smoker and non-smoker diabetic patients as compared to their smoker and non-smoker controls. Other studies (60-61) showed that diabetics are more vulnerable to the damaging effects of long-term exposure to lead, such as renal dysfunction and inflammation.

\section{Limitations and strengths}

The Health Interview Surveys of 1997, 2001 and 2004 enabled us to examine the prevalence of type 2 diabetes in adults of Turkish, Moroccan and Belgian origin in Belgium and to study the risk factors responsible for the differences in the diabetes prevalence between these communities. To our knowledge, this study is the first Belgian study on this subject with data that can be considered as sufficiently representative for the health condition of the population residing in Belgium. Although there is no information available with regard to the nonresponse in the Turkish and Moroccan communities in Belgium, there are no indications that Belgians of Turkish and Moroccan origin are underrepresented. Comparing the percentage of 35- to 74-years-old Belgians of Turkish and Moroccan origin in our sample with the percentage in the census population of 2001 , aged 35 to 74 years old, we find an accurate representation of Turks and Moroccans in HIS 97-01-04.

Next to these strengths, some caveats should also be mentioned. As cited above, the crosssectional character of the Health Interview Surveys makes it difficult to conclude on any causality in the observed associations, although the (causal) direction of associations may be logically inferable. A second limitation is that our data are self-reported, not measured. As stated before, the use of self-reported diabetes probably leads to an underestimation of the actual diabetes prevalence as one third to half of all diabetic people are unaware of the fact that they have diabetes $(1,4)$. In the Netherlands, the Hoorn study indicated that the number 
of unknown (newly detected) diabetics equals the number of known diabetics (62). An additional limitation is the fact that we have no information about this 'unknown versus known diabetes' ratio in Belgians of Turkish and Moroccan origin. However, there are indications that glycaemic control is lower in these communities (63). In any case, we might state that the total prevalence of known and unknown diabetes in these communities will probably be higher than the prevalence found in this study. Moreover, the use of reported height and weight also leads to an underestimation of BMI (34). As regards BMI, we also have no idea about any possible ethnic differences in self-report studies. A third limitation is that some information, such as waist-to-hip ratio, total caloric intake or parity, was not available in HIS 9701-04. Moreover, the number of Belgians of Turkish and Moroccan origin in the sample was relatively small. Consequently, some indicators of physical activity and diet could not be included in the analyses.

\section{Conclusions}

This study provides evidence for a high prevalence and early onset of type 2 diabetes in Belgians of Turkish and Moroccan origin. We identified some risk factors in the higher prevalence in the Turkish and Moroccan communities in Belgium. The most important socioeconomic determinant for the relatively high diabetes prevalence in both men and women of Turkish and Moroccan origin is educational attainment. The influence of lifestyle factors on community differences in diabetes is more complex. In men, a lack of physical activity plays an important part. In women, the higher mean diabetes probability in the Turkish and Moroccan communities is particularly associated with their higher mean BMI. However, some of the ethnic differences in diabetes prevalence in women could not be explained; the odds ratios for Turkish versus Belgian and Moroccan versus Belgian women remain high. In the discussion, we hypothesized that cultural and environmental factors in particular, such as the migration experience, dietary habits and a combination of excess weight and gestational diabetes, may play an important part.

In the light of worldwide ageing and increased corpulence, the diabetes prevalence is still expected to rise. The costs for the individual and the society will be tremendous. Consequently, prevention of type 2 diabetes is extremely important. Moreover, prevention of type 2 diabetes mellitus also gains importance as the same risk factors underlie other disorders, such as cardiovascular and cerebrovascular diseases, and as diabetes is accompanied by an increased death probability. Identification of risk factors and risk groups of diabetes is a conditio sine qua non for an efficient preventive policy. In this study, we already identified one high risk group, namely women of Turkish and Moroccan origin. An active screening of these women - if possibly in collaboration with existing initiatives - should be considered as one of the most important tracks for preventive policy. However, costs and benefits should be weighed up against each other. In this study, we also identified some risk factors: excess weight/obesity and a sedentary leisure lifestyle. Preventive policy of type 2 diabetes should focus on these determinants. A wide range of interventions is possible: alerting to the risks of being overweight/obese, promoting knowledge and skills in the field of healthy eating, en- 
couraging adults of Turkish and Moroccan origin to participate in sports and other types of physical activity. Finally, the results of this study are indicative for a protective effect of educational attainment. A higher educational level is associated with a lower risk of diabetes type 2. Therefore, enduring efforts should be made to improve the educational level of people from the Turkish and Moroccan communities in Belgium. To conclude, further - mainly qualitative - research into the relatively high diabetes prevalence of women in the Turkish and Moroccan communities is necessary in order to unravel the specific - cultural - mechanisms at stake and to fine-tune preventive policy for this target group.

\section{Samenvatting}

Doelstellingen

Het vergelijken van de prevalentie van diabetes type 2 bij volwassenen - 35 tot 74 jaar oud - van de Turkse en Marokkaanse gemeenschap in België met de prevalentie bij autochtone Belgen. Het onderzoeken van de determinanten en specifieke mechanismen die verantwoordelijk zijn voor verschillen in diabetesprevalentie tussen deze gemeenschappen.

Methode

Beide doelstellingen werden onderzocht met behulp van de gezondheidsenquêtes van 1997, 2001 en 2004. Stapsgewijze logistische regressieanalyses werden uitgevoerd met diabetes als afhankelijke variabele. De variabelen 'leeftijd', 'geslacht', 'etnische afkomst', 'body mass index', 'gebrek aan fysieke activiteit', 'opleidingsniveau' en 'inkomen' werden in opeenvolgende stappen in het model geïntroduceerd.

Resultaten

In de leeftijdsgroep van 35 tot 74 jaar is de prevalentie van diabetes type 2 hoger bij Belgen van Turkse en Marokkaanse oorsprong dan bij autochtone Belgen. Bij autochtone Belgische mannen bedraagt de diabetesprevalentie 5,0\%. Bij 35- tot 74-jarige mannen van Turkse en Marokkaanse afkomst is de prevalentie van diabetes type 2 respectievelijk 5,8 \% en 6,5\%. Van de 35- tot 74-jarige vrouwen van Belgische, Turkse en Marokkaanse afkomst heeft respectievelijk 4,3\%, 18,7 \% en 11,9\% diabetes. De verschillen in diabetesprevalentie bij mannen worden veel kleiner na controle voor lichaamsbeweging en opleidingsniveau. Bij vrouwen worden de verschillen kleiner na controle voor BMI en opleidingsniveau, hoewel ze substantieel blijven.

Conclusies

Bij mannen worden de verschillen in diabetesprevalentie verklaard door leefstijlfactoren en opleidingsniveau. Bij vrouwen blijven de gemeenschapsverschillen in diabetesprevalentie bestaan, hoewel leefstijlfactoren en opleidingsniveau een belangrijke rol spelen bij het begrijpen van deze verschillen.

\section{Résumé}

Objectifs

Comparer la prévalence du diabète chez les adultes - âgés de 35 à 74 ans - des communautés turques, marocaines et belges en Belgique. Examiner les déterminants et mécanismes spécifiques, responsables des différences de la prévalence du diabète chez ces communautés. 


\section{Méthodes}

L'étude se base sur les enquêtes de santé belges de 1997, 2001 et 2004. Des régressions logistiques sont appliquées avec le diabète comme variable dépendante. Les variables 'âge', 'sexe', 'origine ethnique', 'body mass index', 'absence d'exercice physique', 'niveau d'éducation' et 'revenus' sont progressivement introduits dans le modèle.

\section{Résultats}

Dans le groupe d'âge de 35 à 74 ans, la prévalence du diabète de type 2 est plus élevée parmi les Belges d'origine turque et marocaine que parmi les Belges autochtones. La prévalence du diabète s'élève à 5,0\% parmi les hommes belges autochtones. Parmi les hommes d'origine turque et marocaine, âgés de 35 à 74 ans, la prévalence du diabète est respectivement de 5,8\% et de 6,5\%. Respectivement 4,3\%, 18,7\% et 11,9\% des femmes d'origine belge, turque et marocaine sont diabétiques. Parmi les hommes, les différences de la prévalence $d u$ diabète se réduisent fortement après contrôle statistique pour l'exercice physique et le niveau d'éducation. Parmi les femmes, les différences persistent, bien qu'elles se réduisent après contrôle statistique pour l'indice de masse corporelle et le niveau d'éducation.

\section{Conclusions}

Parmi les hommes, les différences de la prévalence du diabète sont expliquées par des éléments de style de vie et le niveau d'éducation. Parmi les femmes, les différences persistent, bien que des éléments de style de vie et le niveau d'éducation jouent un rôle important dans ces différences.

\section{References}

1. Capet F, Debaillie R, Van Oyen H, Tafforeau J. Diabetes. Huidige toestand in België en elementen voor een gezondheidsbeleid. Brussel: Afdeling Epidemiologie, Wetenschappelijk Instituut Volksgezondheid. Episerie $\mathrm{N}^{\circ} 19 ; 1999$. Available from: http://www.iph.fgov.be/epidemio/morbidat/nl/zie/ziek04t.pdf

2. Mackenbach JP, Snels IAK, Friden-Kill LM. Diabetes mellitus als doodsoorzaak. Ned Tijdschr Geneeskd 1991; 135(33):1492-6

3. Schernthaner G, Morton JM. Bariatric Surgery in Patients With Morbid Obesity and Type 2 Diabetes. Diabetes Care 2008; 31(Suppl. 2): S297-302

4. International Diabetes Federation. Diabetes atlas. Executive summary. Brussels: International Diabetes Federation; 2003. Available from: http://www.eatlas.idf.org/webdata/docs/Atlas\%202003-Summary.pdf

5. Yki-Järvinen $\mathrm{H}$. The prediction and prevention of non-insulin-dependent diabetes mellitus. In: Pickup JC, Williams G, editors. Textbook of diabetes. Oxford: Blackwell Science; 1997. p. 83.1-11

6. Räikkönen K, Keltikangas-Järvinen L, Adlercreutz H, Hautanen A. Psychosocial Stress and the Insulin Resistance Syndrome. Metabolism 1996; 45(12): 1533-8

7. Björntorp P. Hypothesis. Visceral fat accumulation: the missing link between psychosocial factors and cardiovascular disease? J Intern Med 1991; 230(3): 195-201

8. Leynen F, Moreau M, Pelfrene E, Clays E, De Backer G, Kornitzer M. Job stress and prevalence of diabetes: results from the belstress study. Arch Public Health 2000; 61(1-2): 75-90

9. Middelkoop BJC, van der Wal G. De oorzaken van de hoge prevalentie van diabetes mellitus type 2 onder Hindostanen. TSG 2004; 82(3): 142-52

10. Alexander CM, Landsman PB, Teutsch SM, Haffner SM. NCEP-Defined Metabolic Syndrome, Diabetes, and Prevalence of Coronary Heart Disease Among NHANES III Participants Age 50 Years and Older. Diabetes 2003; 52(5): 1210-4 
11. The Metascreen Writing Committee. The Metabolic Syndrome Is a Risk Indicator of Microvascular and Macrovascular Complications in Diabetes. Results from Metascreen, a multicenter diabetes clinic-based survey. Diabetes Care 2006; 29(12): 2701-7

12. Shai I, Jiang R, Manson JE, Stampfer MJ, Willett WC, Colditz GA, et al. Ethnicity, Obesity, and Risk of Type 2 Diabetes in Women. A 20-year follow-up study. Diabetes Care 2006; 29(7): 1585-90

13. Greenhalgh PM. Diabetes in British South Asians: Nature, Nurture, and Culture. Diabet Med 1997; 14(1): 10-8

14. Kriegsman D, van Langen J, Valk G, Stalman W, Boeke J. Hoge prevalentie van diabetes mellitus type 2 bij Turken en Marokkanen. Huisarts Wet 2003; 46(7): 363-8

15. Dijkshoorn H, Uitenbroek DG, Middelkoop BJC. Prevalentie van diabetes mellitus en hart- en vaatziekten onder Turkse, Marokkaanse en autochtone Nederlanders. Ned Tijdschr Geneeskd 2003; 147(28): 1362-6

16. Middelkoop BJC, Kesarlal-Sadhoeram SM, Ramsaransing GN, Struben HWA. Diabetes mellitus among South Asian inhabitants of The Hague: high prevalence and an age-specific socioeconomic gradient. Int $\mathrm{J}$ Epidemiol 1999; 28(6): 1119-23

17. Middelkoop BJC. General discussion. In: Middelkoop BJC. Diabetes: a true trouble. Studies on cardiovascular risk, ethnicity, socioeconomic position and intervention possibilities. Den Haag: GGD Den Haag; 2001. p. 83-113

18. Carter JS, Pugh JA, Monterrosa A. Non-insulin dependent diabetes mellitus and ethnic minorities. Ann Intern Med 1996; 125(3): 221-32

19. Knowler WC, Pettitt DJ, Saad MF, Bennett PH. Diabetes mellitus in the Pima Indians: incidence, risk factors and pathogenesis. Diabetes Metab Reviews 1990; 6(1): 1-27

20. Ferrant L. De zin van het verschil: Culturele diversiteit in grootstedelijke praktijken. Symposium Ethiek en economie; 19 April 2007; Brussel: Doktersgild Van Helmont. Available from: http://www.doktersgildvanhelmont.be/documenten/ee7ferrant.pdf

21. Koning Boudewijnstichting. Gezondheidszorg en diversiteit. Het voorbeeld van de moslimpatiënten. Brussel: KBS; 2005.

22. Yildiz G, Avonts D, Van Gaal L, Van Royen P. Diabetes type 2 bij allochtonen. Hogere incidentie, meer complicaties en toch een vergeten groep. Huisarts Nu 2005; 34(9): 510-7

23. Deboosere P, Gadeyne S. Adult Migrant Mortality Advantage in Belgium: Evidence using Census and Register Data. Population 2005; 60(5-6): 655-98

24. Stronks K, Uniken Venema P, Dahhan N, Gunning-Schepers LJ. Allochtoon, dus ongezond? Mogelijke verklaringen voor de samenhang tussen etniciteit en gezondheid geïntegreerd in een conceptueel model. TSG 1999; 77(1): 33-40

25. Baschetti R. Diabetes epidemic in newly westernized populations: is it due to thrifty genes or to genetically unknown foods? J R Soc Med 1998; 91(12): 622-5

26. Cruickshank JK, Mbanya JC, Wilks R, Balkau B, McFarlane-Anderson N, Forrester T. Sick genes, sick individuals or sick populations with chronic disease? The emergence of diabetes and high blood pressure in African-origin populations. Int J Epidemiol 2001; 30(1): 111-7

27. Beck M, Vanroelen C, Louckx F. Sociaal-economische verschillen in leefstijl: de Belgische situatie. In: Beck M, Vanroelen C, Louckx F. Sociale breuklijnen in de gezondheid en de gezondheidszorg. Brussel: VUBpress; 2002. p. $113-60$

28. Satman I, Yilmaz T, Sengül A, Salman S, Salman F, Uygur S, et al. Population-Based Study of Diabetes and Risk Characteristics in Turkey. Results of the Turkish Diabetes Epidemiology Study (TURDEP). Diabetes Care 2002; 25(9): 1551-6

29. Tazi MA, Abir-Khalil S, Chaouki N, Cherqaoui S, Lahmouz F, Sraïri JE, Mahjour J. Prevalence of the main cardiovascular risk factors in Morocco: results of a National Survey, 2000. J Hypertens 2003; 21(5): 897-903

30. Demarest S, Leurquin P, Tafforeau J, Tellier V, Van der Heyden J, Van Oyen H. Health of the population in Belgium. Health Survey by means of interview, Belgium, 1997. Brussels: Epidemiology Unit, Scientific Institute of Public Health; 1998. Available from: http://www.iph.fgov.be/epidemio/epinl/crospnl/hisnl/table97.htm 
31. Demarest S, Van der Heyden J, Gisle L, Buziarsist J, Miermans PJ, Sartor F, et al. Health Survey by means of interview, Belgium, 2001. IPH/EPI Reports $\mathrm{N}^{\circ}$. 2002-25. Brussels: Epidemiology Unit, Scientific Institute of Public Health; 2002. Available from: http://www.iph.fgov.be/epidemio/epinl/crospnl/hisnl/table01.htm

32. Bayingana K, Demarest S, Gisle L, Hesse E, Miermans PJ, Tafforeau J, et al. Health Survey by means of interview, Belgium, 2004. IPH/EPI Reports N. 2006-034. Brussels: Epidemiology Unit, Scientific Institute of Public Health; 2006. Available from: http://www.iph.fgov.be/epidemio/epifr/crospfr/hisfr/table04.htm

33. Beck M, Vanroelen C, Louckx F. Het verklaren van sociaal-economische gezondheidsverschillen. In: Beck M, Vanroelen C, Louckx F. Sociale breuklijnen in de gezondheid en de gezondheidszorg. Brussel: VUBpress; 2002; p. 33-44

34. Østbye T, Welby TJ, Prior IAM, Salmond CE, Stokes YM. Type 2 (non-insulin-dependent) diabetes mellitus, migration and westernisation: The Tokelau Island Migrant study. Diabetologia 1989; 32(8): 585-90

35. Demarest S, Gisle L, Hesse E, Tafforeau J, Van der Heyden, J. Health Interview Survey Belgium. MANUAL 2004. Database 1997-2001-2004. Version November 2006/2. Brussels: Epidemiology Unit, Scientific Institute of Public Health; 2006

36. Duvigneaud N, Wijndaele K, Matton L, Deriemaeker P, Philippaerts R, Lefevre J, et al. Prevalence of overweight, obesity and abdominal obesity in Flemish adults. Arch Public Health 2006; 64(4): 123-42

37. Roberts RJ. Can self-reported data accurately describe the prevalence of overweight? Public Health 1995; 109(4): 275-84

38. Dobbelsteyn CJ, Joffres MR, MacLean DR, Flowerdew G, the Canadian Heart Health Survey Research Group. A comparative evaluation of waist circumference, waist-to-hip ratio and body mass index as indicators of cardiovascular risk factors. The Canadian Heart Health Surveys. Int J Obes Relat Metab Disord 2001; 25(5): 652-61

39. Hanson RL, Narayan KMV, McCance DR, Pettitt DJ, Jacobsson LTH, Bennett PH, Knowler WC. Rate of Weight Gain, Weight Fluctuation, and Incidence of NIDDM. Diabetes 1995; 44(3): 261-6

40. Reniers G. On the History and Selectivity of Turkish and Moroccan Migration to Belgium. Int Migration 1999; 37(4): 679-713

41. Bergvall N, Cnattingius S. Familial (shared environmental and genetic) factors and the foetal origins of cardiovascular diseases and type 2 diabetes: a review of the literature. J Intern Med 2008; 264(3): 205-23

42. Hales CN, Barker DJP. Type 2 (non-insulin-dependent) diabetes mellitus: the thrifty phenotype hypothesis. Diabetologia 1992; 35(7): 595-601

43. Hattersley AT, Tooke JE. The fetal insulin hypothesis: an alternative explanation of the association of low birthweight with diabetes and vascular disease. Lancet 1999; 33(9166): 1789-92

44. Traa MJA. Diabetes mellitus bij Turken. In: Malki FS, Nieuwelink JJC, Traa MJA, Waterval LA, editors. Voeding bij diabetes mellitus. Dieetbegeleiding van Turkse, Marokkaanse en Hindostaanse bevolkingsgroepen. Houten: Bohn Stafleu van Loghum; 2005. p. 32-51

45. Malki FS, Waterval LA. Diabetes mellitus bij Marokkanen. In: Malki FS, Nieuwelink JJC, Traa MJA, Waterval LA, editors. Voeding bij diabetes mellitus. Dieetbegeleiding van Turkse, Marokkaanse en Hindostaanse bevolkingsgroepen. Houten: Bohn Stafleu van Loghum; 2005. p. 52-67

46. Branth S, Ronquist G, Stridsberg M, Hambraeus L, Kindgren E, Olsson R, Carlander D, et al. Development of abdominal fat and incipient metabolic syndrome in young healthy man exposed to long-term stress. Nutr Metabolism Cardiovasc Dis 2007; 17(6): 427-35

47. Mooy JM, De Vries H, Grootenhuis PA, Bouter LM, Heine RJ. Major Stressful Life Events in Relation to Prevalence of Undetected Type 2 Diabetes. The Hoorn Study. Diabetes Care 2000; 23(2): 197-201

48. Agardh EE, Ahlbom A, Andersson T, Ependic S, Grill V, Hallqvist J, Norman A, et al. Work Stress and Low Sense of Coherence Is Associated With Type 2 Diabetes in Middle-Aged Swedish Women. Diabetes Care 2003; 26(3): 719-24

49. Mirdal GM. Stress and Distress in Migration: Twenty Years After. Int Migration Rev 2006; 40(2): 375-89

50. Bottalico JN. Recurrent Gestational Diabetes: Risk Factors, Diagnosis, Management and Implications. Semin Perinatol 2007; 31(3): 176-84 
51. Cloots H, De Kind H, Kongs A, Smets H. Gezondheidsindicatoren 2004 Vlaams Gewest. Geboorte en bevalling. Brussel: Vlaams Agentschap Zorg \& gezondheid; 2006. Available from: http://www.zorg-engezondheid.be/uploadedFiles/NLsite/Cijfers/Gezondheidsindicatoren/GI2004_geboorte_bevalling.pdf

52. Hutse V, Claeys F, Mertens K. Epidemiologische surveillance bij de algemene bevolking. Zware metalen en oligo-elementen in het bloed. IPH/EPI REPORTS N. 2006-30. Brussel: Afdeling Epidemiologie; Wetenschappelijk Instituut Volksgezondheid; 2006. Available from: http://www.iph.fgov.be/EPIDEMIO/epinl/envinl/D_2006_2505_46.pdf

53. Keen RW, Deacon AC, Delves HT, Moreton JA, Frost PG. Indian herbal remedies for diabetes as a cause of lead poisoning. Postgrad Med J 1994; 70(820): 113-4

54. Petit D, Claeys F, Sykes C, Noefnet $Y$. Lead poisoning from metallic teapots traditionally used by North African populations. J Phys IV France 2003; 107(2): 1053-6

55. Levecque K, Lodewijckx I, van den Eeden S. Gezondheid en gezondheidszorg bij allochtonen in Vlaanderen. Steunpunt Gelijkekansenbeleid - Consortium Universiteit Antwerpen en Universiteit Hasselt. Antwerpen: Drukkerij Peten Print; 2006

56. Schwartz J. Lead, Blood Pressure, and Cardiovascular Disease in Men. Arch Environ Health 1995; 50(1): 31-7

57. Navas-Acien A, Guallar E, Silbergeld E, Rothernberg SJ. Lead Exposure and Cardiovascular Disease - A Systematic Review. Environ Health Perspect 2007; 115(3): 472-82

58. Bener A, Obineche E, Gillett M, Pasha MAH, Bishawi B. Association between blood levels of lead, blood pressure and risk of diabetes and heart disease in workers. Int Arch Occup Environ Health 2001; 74(5): 375-8

59. Afridi HI, Kazi TG, Kazi N, Jamali MK, Arain, MB, Jalbani N, Baig JA, et al. Evaluation of status of toxic metals in biological samples of diabetes mellitus patients. Diabetes Res Clin Pract 2008; 80(2): 280-8

60. Tsaih S-W, Korrick S, Schwartz J, Amarasiriwardena C, Aro A, Sparrow D, Hu H. Lead, Diabetes, Hypertension, and Renal Function: The Normative Aging Study. Environ Health Perspect 2004; 112(11): 1178-82

61. Lin J-L, Lin-Tan D-T, Yen T-H, Hsu C-W, Jenq CH-C, Chen K-H, Hsu K-H et al. Blood Lead Levels, Malnutrition, Inflammation, and Mortality in Patients With Diabetes treated by Long-Term Hemodialysis. Am J Kidney Dis 2008; $51(1): 107-15$

62. Mooy JM, Grootenhuis PA, de Vries H, Valkenburg HA, Bouter LM, Kostense PJ, Heine RJ. Prevalence and Determinants of Glucose Intolerance in a Dutch Caucasian Population. Diabetes Care 1995 ; 18(9): 1270-3

63. Levecque K, Lodewijckx I, van den Eeden S. Gezondheid en gezondheidszorg bij allochtonen in Vlaanderen. Steunpunt Gelijkekansenbeleid - Consortium Universiteit Antwerpen en Universiteit Hasselt. Antwerpen: Drukkerij Peten Print; 2006 